\title{
Efficiency of Future Engineers' Professional Independence Formation Under the Conditions of Educational Environment Profiling
}

\author{
Elena Mikhaylovna Kargina \\ PhD in Pedagogical Science, Penza State University of Architecture and Construction, Russia \\ kargina-elena@mail.ru
}

\author{
Doi:10.5901/mjss.2015.v6n6p541
}

\section{Abstract}

Professional engineers have to apply their analytical skills and well developed understanding of scientific principles and engineering theory to work out original solutions of complex problems. It requires from future engineers a certain degree of independence, responsibility, mobility, readiness for self-knowledge and an ability of self-realization in professional activity. Efficiency of future engineers' professional independence formation under the conditions of educational environment profiling is analyzed. Results of experimental data monitoring according to criterion of future engineers independence are presented.

Keywords: professional independence formation, training of engineers, educational environment profiling, technical higher education, efficiency

\section{Introduction}

Professional engineers apply lifelong learning, critical perception and engineering judgment to the performance of engineering services. They challenge current thinking and conceptualize alternative approaches, often engaging in research and development of new engineering principles, technologies and materials (Kaspura, A., 2011). The solution of these tasks demands from future engineers certain personal qualities, in particular an ability to act, judge and make decisions independently. Educational process has to be aimed at forming and developing these characteristics.

E.F. Zeer and G.M. Romantsev define independence and ability to make crucial decisions as necessary qualities of the modern specialist personality which formation is possible in the conditions of the profile education (Zeer, E.F. \& Romantsev, G.M., 2002).

One of the realization ways of the profile personally focused education is the University educational complex of the Penza State University of Architecture and Construction. Continuous profile education at the university complex is aimed at transforming an education object into a subject of self-education and self-development (Kargina, E.M., 2015).

To achieve this purpose there should be developed some need for self-education. Participation in social pedagogical projects realized in a university educational complex («Integrative continuity of professional education main stages», "Realization of the training continuity principle in the conditions of versatile educational complex activity», «Complex stage-by-stage system of continuous practical training and employment of higher educational institutions students» (Kargina, E.M., 2007)) encourage students to determine the tasks and to solve them independently (Blumenfeld, P.C., 1991).

The realization of the social pedagogical project «Integrative continuity of professional education main stages» was enabled in the form of the following algorithm: kindergarten $\rightarrow$ school $\rightarrow$ college $\rightarrow$ university $\rightarrow$ enterprise.

\subsection{Project purpose}

Implementation of the project is directed on:

- early detection of children's interests and abilities, since preschool age;

- ensuring quality training in establishments of preschool, general and professional education of the profile educational environment;

- improvement of pupils' adaptation quality upon their transition to training at profile educational institutions of higher level or to production;

- development of intellectual potential of the region. 


\subsection{Project tasks}

- development and deployment of the regional educational standards providing high quality of training;

- development and deployment of non-standard educational programs and projects in training;

- monitoring of training quality at each stage of profile education;

- development and deployment of the programs intended for work with children at early grade levels in profile educational institutions;

- development of the curricula and programs, educational and methodical grants providing continuity and integration of education.

\subsection{Contents of the project}

- realization of University Educational Complex innovative structure;

- development of the strategic development plan of University Educational Complex and information infrastructure for interaction with labor market, enterprises;

- development of normative documents set and methodical recommendations for the organization of University Complex activity;

- creation of the necessary and sufficient information environment for support of educational and scientific activity of University Educational Complex members;

- providing participants of pedagogical process with professional information at all stages of socialization on special programs under the Conditions of Educational Environment Profiling. Mastering pupils of comprehensive schools a certain set of social, economic and psycho physiological conditions knowledge of a profession right choice, informing on the most general signs of a profession is provided;

- methodical and technological support of pedagogical process participants at all stages of University Educational Complex activity;

- exchange of experience of university complexes pedagogical collectives at conferences and seminars.

\section{Experimental Study}

Professional independence is an important quality of a future engineer. The research of this characteristic was carried out by means of the technique «The independence level» (Dudman, A., Wearne, S.H. 2003). The results received when studied the control and experimental groups of beginners training at the Penza State University of Architecture and Construction are given in Table 1.

Table 1: Results of the students testing using the technique «The independence level»

\begin{tabular}{|c|l|c|c|}
\hline Points & Interpretation & Control group & Experimental group \\
\hline $30-44$ & Excessive independence & $2 \%$ & $11 \%$ \\
\hline $15-29$ & Sufficient level of independence & $19 \%$ & $81 \%$ \\
\hline $0-14$ & Indecision & $79 \%$ & $8 \%$ \\
\hline
\end{tabular}

The most part (79\%) of the beginners training at traditional educational institutions (control group) are excessively indecisive. The shortage of independence explains passivity and the fact that the future professional activity was chosen by accident. Parents and teachers didn't develop independence or determination and influenced much on the students' decision on the future specialization and a choice of higher education institution. But this influence wasn't just a form of advice but carried authoritative character.

Independent applicants who were afraid of failure entered the higher education institution without following their interests and abilities. Thus they chose the most available establishment.

Only 19\% of respondents in control group possess a rather developed level of independence and $2 \%$ of them are excessively independent in acts and decisions.

Thus, in general only $21 \%$ of all applicants from control group are capable to independent decision-making, statement of the purposes and possess a necessary share of commitment to achieve a goal.

The results received in experimental group are different (Figure 1). The prevailing part of students: $81 \%$ and $11 \%$ gained more than 15 points that proves a high degree of the personality independence. Only $8 \%$ of respondents are 
indecisive or dependent. It explains the fact of early choice of profession and a way of its achievement - the University Educational Complex. In an educational complex the considerable attention is paid to the development of independence.

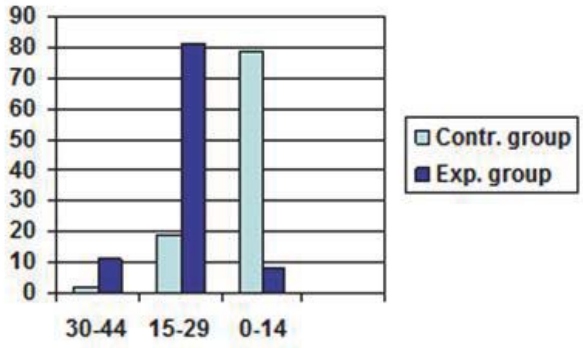

\section{Decrease of independence}

Figure 1. Results of the students testing using the technique «The independence level»

Test technique «Are you independent?» (Godlinik, O.B. \& Solovyova, E.A., 2005) was offered for university senior students (4-5th year students). The received results are given in Table 2.

Table 2: Results of the senior students testing using the technique «The independence level»

\begin{tabular}{|c|l|c|c|}
\hline Points & Interpretation & Control group & Experimental group \\
\hline $30-44$ & Excessive independence & $7 \%$ & $18 \%$ \\
\hline $15-29$ & Sufficient level of independence & $42 \%$ & $77 \%$ \\
\hline $0-14$ & Indecision & $51 \%$ & $5 \%$ \\
\hline
\end{tabular}

There are the following changes on the histogram (Figure 2). The number of indecisive students of control group was reduced: from $79 \%$ to $51 \%$. On the other hand, the number of the students capable of independent decision-making was increased. However total indicators testify to insufficient number of graduates, independent in acts, judgments and decisions.

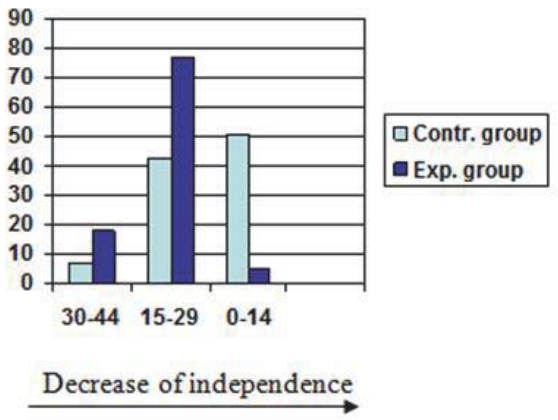

Figure 2. Results of the graduates testing using the technique «The independence level»

In experimental group there were positive changes. The number of the students who gained more than 15 points (sufficient level of independence) increased from 92\% to 95\%. It was a consequence of the students' traditional respect for independence that was developed at some establishment of the University Educational Complex.

Testing of young specialists using this technique showed some changes (Table 3). 
Table 3: Results of the specialists testing using the technique «The independence level»

\begin{tabular}{|c|l|c|c|}
\hline Points & Interpretation & Control group & Experimental group \\
\hline $30-44$ & Excessive independence & $18 \%$ & $27 \%$ \\
\hline $15-29$ & Sufficient level of independence & $50 \%$ & $72 \%$ \\
\hline $0-14$ & Indecision & $32 \%$ & $1 \%$ \\
\hline
\end{tabular}

Both in control and experimental groups the positive tendencies noted in the category «Graduates of the Penza State University of Architecture and Construction» are traced: the number of uncertain young people has decreased considerably, but this indicator is much lower in experimental group - $1 \%$ indecisive students in experimental group as compared with $32 \%$ in control group (Figure 3).

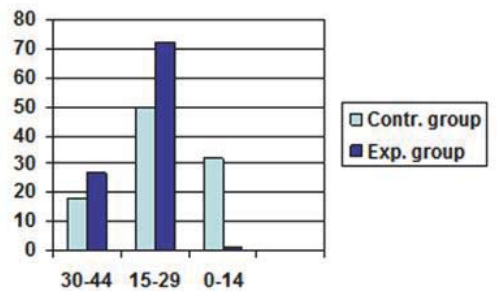

\section{Decrease of independence}

Figure 3. Results of the specialists testing using the technique «The independence level»

The changes of all allocated categories in control and experimental groups are shown in summary Table 4 and on histograms (Figures 4a\&4b):

Table 4: Results of testing using the technique «Are you independent?»

\begin{tabular}{|c|l|c|c|c|c|c|c|}
\hline \multirow{2}{*}{ Points } & \multirow{2}{*}{ Interpretation } & \multicolumn{2}{|c|}{ Students } & \multicolumn{2}{|c|}{ Graduates } & \multicolumn{2}{c|}{ Specialists } \\
\cline { 3 - 8 } & & CG & EG & CG & EG & CG & EG \\
\hline $30-44$ & Excessive independence & $2 \%$ & $11 \%$ & $7 \%$ & $18 \%$ & $18 \%$ & $27 \%$ \\
\hline $15-29$ & Sufficient level of independence & $19 \%$ & $81 \%$ & $42 \%$ & $77 \%$ & $50 \%$ & $72 \%$ \\
\hline $0-14$ & Indecision & $79 \%$ & $8 \%$ & $51 \%$ & $5 \%$ & $32 \%$ & $1 \%$ \\
\hline
\end{tabular}

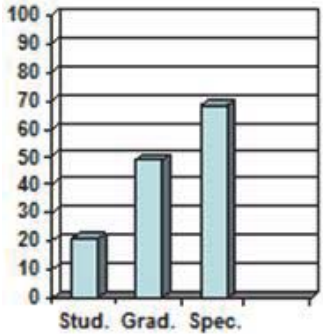

a

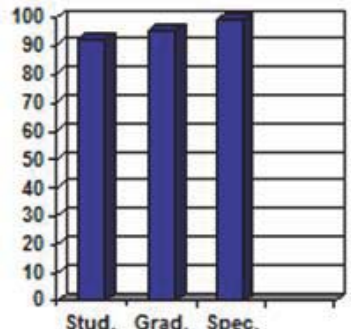

b

Figure 4. Increase of the students' number with the high level of independence 


\section{Conclusions}

The skills and expertise of engineers in delivering engineering services are unique. Some skills have substitutes or training requirements that can be quickly completed. There are no substitutes for engineers because training is highly specialized, the necessary period of training is long and intense and academic training is just the precursor to the development of practical skills and expertise necessary to be a competent practicing engineer (Kaspura, A., 2013).

Formation of the personality readiness for self-development and self-education being a basis for conscious and high-quality self-determination represents one of the ways to transfer external administrative actions into a system of selfcorrection.

Educational activity of a university complex promotes formation and development of students' professional independence on the basis of their active participation in social and pedagogical projects. It develops their persistence and commitment in practical mastering of a profession or specialty, gives a chance of practical application of the gained theoretical knowledge, self-assessments of the intellectual, emotional and strong-willed qualities.

The formed professional independence of future engineers is realized:

- in ability to make an independent choice on the ways of work performance providing high quality and labor productivity;

_ $\quad$ in ability to make original decisions on the current production situation, to make the correct decision;

- in ability to plan and control independently the performed work.

\section{References}

Blumenfeld, P.C. (1991). Motivating project-based learning: sustaining the doing, supporting the learning, Educational Psychologist, 26, 369-398.

Dudman, A. \& Wearne, S.H. (2003). Professional Engineers' Needs for Managerial Skills and Expertise, Centre for Research in the Management of Projects, University of Manchester Institute of Science \& Technology.

Godlinik, O.B. \& Solovyova, E.A. (2005). Modern practical psychology. Moscow: Academia.

Kargina, E.M. (2015). Efficiency of Training of Engineers in the Conditions of Educational Environment Profiling of Technical Higher Education. Contemporary Engineering Sciences, Vol. 8, 2015, no. 2, 49-56. http://dx.doi.org/10.12988/ces.2015.412269.

Kargina, E.M. (2015). Professional Motivation Formation of Future Specialists under the Conditions of Regional Educational Complex. International Education Studies, Vol. 8, No. 7, 44-56. http://dx.doi.org/10.5539/ies.v8n7p44.

Kargina, E.M. (2015). The Analysis of Educational Projects for Continuous Training of Engineers at Various Stages of the Profile Educational Environment. Contemporary Engineering Sciences, Vol.8, 2015, no.7, 323-328. http://dx.doi.org/10.12988/ces. 2015.5226.

Kargina, E.M. (2007). Theoretical and methodological bases of pedagogical process profiling in technical higher education institutions, Monograph, Moscow.

Kaspura, A. (2013). The Engineering Profession: A Statistical Overview, Tenth Edition.

Zeer, E.F. \& Romantsev, G.M. (2002). Personally focused professional education, Pedagogics, 3, 16-21. 